\title{
Risk factors associated with resolution of diabetic ketoacidosis in pediatric critical care units
}

\section{Çocuk yoğun bakımda izlenen diabetik ketoasidoz olgularında ketoasidozdan faktörler}

\author{
Ebru Atike Ongun¹, Nurullah Celik
}

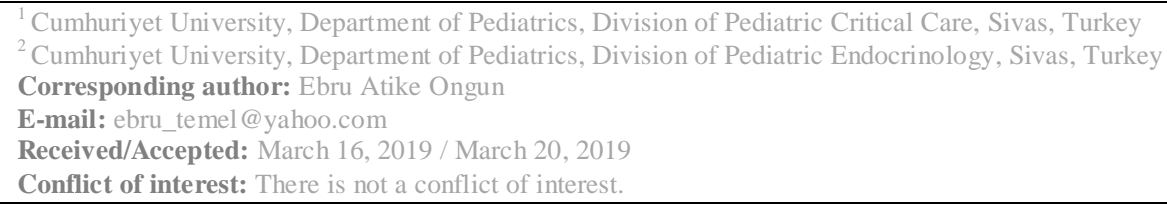

\section{SUMMARY}

Objective: Diabetic ketoacidosis (DKA) is the main cause of morbidity and mortality in children with type-I Diabetes Mellitus. The goals of therapy are to correct dehydration, resolution of acidosis and fading of ketosis. Such serious complications necessitate closed monitoring of DKA patients with delicate, balanced therapy, probably at an intensive care facility. Regarding the fact that, each facility shoul determine the clinical profile of their own patient population, we aimed to investigate the risk factors for consequences and determine the timing of DKA resolution by analyzing the demographic and epidemiologic data, clinical outcome and the prognosis of diabetic ketoacidotic children admitted to PICU.

Method: This descriptive, retrospective study was conducted in 105 children admitted to PICU with the complaints of DKA between January 2014 and December 2108. Demograhic data including age, gender, weight, height, body mass index (BMI), initial compliants with clinical findings and level of consciousness were recorded. Children were categorized into two groups depending on the timing of DM diagnosis (new onset of diabetes and established diabetes mellitus). DKA severity was determined by the degree of metabolic acidosis (mild, moderate, severe). SPSS-23 was used for statictics. Descriptive analyses were expressed as percentages, mean \pm standart deviation (SD), median with minimum and maximum values. Chi square and Fischer exact test were used for comparison of categorical variables. Student's t-test, Mann Whitney U test and Wilcoxon rank sum test were assessed for continous variables. Pearson correlation coefficient and logistic regressions were used for correlations and to determine the risk factors. P-value < 0.05 was considered significant.

Results: The patient demographics presented the mean age as $11.31 \pm 4.18$ years, female/male ratio $1 / 1.4$ and body mass index 18.48 \pm 4.48 . Children were classified as mild DKA (29.5\%), moderate DKA (35.2\%) and severe DKA (35.2\%) based on the acidosis severity. $48.6 \%$ of the patients had Kusmaull respiration; $30.5 \%$ had manifested altered consciousness. One patient had tomography-proven brain edema and had required mechanical ventilation due to neurological incapability to sustain airway. Children with new onset of diabetes accounted for $51.4 \%$ of the study population. The mean age was $9.70 \pm 4.47$ years; this group constituted a younger population compared the established DM patients $(\mathrm{p}<0.001)$. Altered mental state and kusmaull respiration also occurred at a higher rate and the major complaint seemed ae weight loss within two weeks $(\mathrm{p}=0.006, \mathrm{p}=0.002, \mathrm{p}<0.001$ respectively). Children with established diabetes mellitus presented significant biochemical abnormalities in terms of elevated BUN and serum potassium levels $(\mathrm{p}<0.001, \mathrm{p}<0.001)$; infections occurred as the major triggering factor for DKA at a rate of $80.4 \%$ at this group. We observed a positive correlation with DKA resolution with serum creatinine, calculated osmolality, anion gap $(\mathrm{r}=0.242, \mathrm{r}=0.215, \mathrm{r}=0.302)$ and a negative correlation with blood gas $\mathrm{pH}$ and $\mathrm{HCO} 3(\mathrm{r}=-0.704, \mathrm{r}=-0.694)$. In the multivariable regression model including age, gender, body mass index, PRISM-3 score, BUN, serum potassium, phosphate and chloride, only blood gas $\mathrm{pH}$ and new onset of diabetes appeared to be the independent risk factors for DKA resolution. 0.1 unit decrement in blood gas $\mathrm{pH}$ elongated the resolution by 3.76 hours $(\mathrm{p}<0.001$, adjusted ratio: $0.743)$. New onset of diabetes mellitus also increased the length of resolution by 5.30 hours $(\mathrm{p}<0.001)$. 
Conclusions: Initial blood gas $\mathrm{pH}$ and presence of new onset of diabetes are the major risk factors in resolution of ketoacidosis.

Keywords: Type 1 Diabetes Mellitus,Ketoacidosis,Risk Factors,Children,Pediatric Critical Care

\section{ÖZET}

Amaç: Diabetik ketoasidoz (DKA), Tip I diabetes mellitusta (DM) mortalite ve morbiditeye neden olan en önemli faktörlerdendir. Bu çalışma ile hastaların geliş laboratuvar ve klinik bulgularından yola çıkarak, ketoasidozdan çıkma sürelerini ön görmeyi ve gelişebilecek komplikasyonlar açısından risk faktörlerini belirlemeyi amaçladik.

Yöntem: Ocak2014-Aralık2018 arasında, Sivas Cumhuriyet Üniversitesi Hastanesi çocuk yoğun bakım servisine (ÇYB), DKA nedeniyle yatan 105 hastanın verileri geriye dönük incelendi. Hastaların demografik verileri, başvuru şikayetleri, muayene bulguları, laboratuvar parametreleri, PRISM skorları, ketoasidozdan çıkış zamanı ile ÇYB ve hastane yatış süreleri kaydedildi. Dehidratasyon derecesine göre ketoasidoz şiddeti (hafif/orta/ağır) derecelendirildi Olgular, yeni ve eski tanılı hastalar olarak iki gruba ayrıldı. SPSS23 ile kategorik ve sayısal veriler değerlendirildi; korelasyon ve çok değişkenli regresyon analizi yapıldı.

Bulgular: Ortalama yaşın 11.31 \pm 4.18 yıl, kı/erkek oranının 1/1.4 olduğu çalışmada yeni tanı alan hastaların oranı \%51.4 idi. Hastaların \%29.5’u hafif, \%35.2'si orta, \%35.2'si ağır şiddette DKA olduğu görüldü. Bilinç değişikliği \%30.5, kusmaull solunum \%48.6 gözlenirken, takiplerde bir hastada entübasyon ihtiyacı doğdu. Dört hastada akut böbrek yetmezliği gelișirken bir olguda hemodiyaliz uygulandı. Ketoasidozdan çıkış süresi ortalama $14.30 \pm 6.43$ saat olup, ÇYB ve hastane yatış süreleri sırasıyla 2.06 1.01 gün ve $7.31 \pm 2.11$ gündü. Her iki grup karşılaştırıldığında, yeni tanı alan hastaların yaşlarının daha küçük, bilinç bulanıklığı ve kusmaul solunum sıklığının daha fazla olduğu görüldü $(p<0.001,(p=0.006, p=0.002$, sırası ile). Öte yandan bu grupta, kilo kaybının en belirgin başvuru şikayeti olduğu görüldü ( $\mathrm{p}<0.001)$. Önceden tanı alan diabetik hastalarda ise, enfeksiyonların \% 80.4 orannda ketoasidoza girme nedeni olduğu ( $\mathrm{p}<0.001$ ); BUN ve serum potasyum düzeylerinin daha yükksek olduğu görüldü (sirasiyla p<0.001, $p<0.001$ ). Ketoasidozdan çıkış süresiyle, serum kreatinin, anyon açığı ve hesaplanan ozmolarite değerlerinin pozitif korele olduğu görüldü (sırasıyla $\mathrm{r}=0.242, \mathrm{r}=0.302, \mathrm{r}=0.215$ ). Çoklu regrasyon modelinde ise kan gazı $\mathrm{pH}$ 'da her 0.1 birimlik düșüșün ketoasidozdan çıkma süresini 3.76 saat, yeni tanı hastalık durumunun ise 5.30 saat geciktirdiği saptandı (adjusted ratio:0.743, p>0.001).

Sonuç: DKA lu olgularda başvuru esnasındaki kan pH değeri ve yeni tanı diabetes mellitus varlığı ketoasidozdan çıkışı belirleyen en önemli faktörlerdir.

Anahtar sözcükler: Tip 1 Diabetes Mellitus, Ketoasidoz, Risk Faktörleri, Çocuk, Çocuk Yoğun Bakım

\section{INTRODUCTION}

Diabetic ketoacidosis (DKA) is the main cause of morbidity and mortality in children with type-I Diabetes Mellitus (T1DM1) ${ }^{1}$. The life-threatining problems occur as a result of secondary dehydration and the multiple biochemical alterations (sodium, potassium, chloride and phosphate) as well as metabolic imbalance ${ }^{2,3}$. The endogenous insulin deficiency with the comibnation of stress activates stress-related counter-regulatory hormones (catecholamines, cortisol, glucagon, growth hormone) which trigger glycogenolysis and gluconeogenesis. Thus the hepatic and renal glucose production increase and lipolysis occur due to deterioration of peripheral glucose utilization. The final outcome is the catabolic metabolic state with hyperglycemia, hyperosmolarity, keton body production and accumulation of acid metabolites (ketones and ketoacids $)^{4}$. International Society for Pediatric and Adolescent Diabetes (ISPAD) guideline refers to DKA as hyperglycemia (blood glucose $>200 \mathrm{mg} /$ $\mathrm{dL}$ ), metabolic acidosis (venous blood gas $\mathrm{pH}<$
7.3 and/or plasma bicarbonate $<15 \mathrm{mmol} / \mathrm{L}$ ) and presence of ketonemia and ketonuria ${ }^{5}$.

The clinical manifestations vary greatly and the incidence of complications are reported from 15\% to $67 \%{ }^{2,6}$. Several risk factors are associated with ketoacidosis such as misdiagnosis at first visit, delay in treatment, previous infection history, younger age $(<2$ years), low body mass index, low economic status with no health insurance ${ }^{1}$. Cerebral edema is one of the most feared consequence of DKA in both short and long term prognosis ${ }^{7}$. Goals of therapy are to correct dehydration, resolution of acidosis and fading of ketosis. Such serious complications necessitate closed monitoring of DKA patients with delicate, balanced therapy, probably at an intensive care facility $^{5}$. The pediatric intensive care unit (PICU) of Sivas Cumhuriyet University Hospital is a tertiary critical care unit serving to a considerably populated territory around the region, The management of therapy are arranged with the collaboration of pediatric endocrinology department. Regarding the fact that, each facility should determine the clinical profile of their own 
patient population ${ }^{8}$, we aimed to investigate the risk factors for consequences and determine the timing of DKA resolution by analyzing the demographic and epidemiologic data, clinical outcome and the prognosis of diabetic ketoacidotic children admitted to PICU.

\section{MATERIAL AND METHODS}

Following approval of the local ethics committee, this descriptive, retrospective study was conducted at DKA children admitted to PICU between January 2014 and December 2108. The search of the ICD code "'ketoacidosis, with diabetes mellitus" on hospital computer database presented 196 PICU admission of 105 children. In case of recurrent admissions, only the first intensive care admissions were collected for analysis. The term DKA was defined by the he Society of Pediatric Emergency and Intensive Care Medicine protocol and 2018 ISPAD guideline suh as: Hyperglycemia (blood glucose $>11 \mathrm{mmol} / \mathrm{L}$ [200 mg/dL]), Venous $\mathrm{pH}<7.3$ or serum bicarbonate $<15 \mathrm{mmol} / \mathrm{L}$, presence of ketonemia or ketonuria ${ }^{5,9}$. Demograhic data including age, gender, weight, height, body mass index (BMI), initial compliants with clinical findings and level of consciousness were recorded. Children were categorized into two groups depending on the timing of DM diagnosis (new onset of diabetes and established diabetes mellitus). DKA severity was determined by the degree of metabolic acidosis: mild DKA as blood gas $\mathrm{pH}<7.30$ or serum bicarbonate $(\mathrm{HCO} 3)<15$; moderate DKA as blood gas $\mathrm{pH}<7.20$ or $\mathrm{HCO} 3<10$ and severe DKA as blood gas $\mathrm{pH}<7.10$ or $\mathrm{HCO} 3<5$ (5). Initial (PICU arrival) biochemical results including serum glucose, sodium, chloride,

\section{RESULTS}

potassium, phosphate, blood urea nitrogen (BUN), creatinine and blood gas parameters $(\mathrm{pH}, \mathrm{HCO} 3$, base excess $[\mathrm{BE}]$ ) were extracted from the database. The corrected sodium (measured $\mathrm{Na}+$ $1.6 \mathrm{x}$ [serum glucose-100] / 100), efective osmolality $(\mathrm{mOsm} / \mathrm{kg})\left(\left[2 \times\right.\right.$ serum $\left.\mathrm{Na}^{+}\right]+[$serum glucose $\div 18])$ and anion gaps $\left(\mathrm{Na}^{+}-\left[\mathrm{Cl}^{-}\right.\right.$ $\left.+\mathrm{HCO}^{-}\right]$) were calculated by the mathematical modelings in parenthesis mentioned above. 'Timing of DKA resolution' was defined as, recovery of consiousness with blood gas $\mathrm{pH}$ over $7.30, \mathrm{HCO}^{-}>15 \mathrm{meq} / \mathrm{L}$ and resolution of ketosis or ketonemia. If any, the complications observed the PICU follow up, PRISM-3score, length of PICU stay and hospitalization were recorded.

SPSS (Statistical Package for Social Sciences) for Windows 23 was used for statics of the study. Descriptive analyses were expressed as percentages, mean \pm standart deviation (SD), median with minimum and maximum values. Chi square and Fischer exact test were used for comparison of categorical variables. Normal and non-normal distributions of continous variables were assessed by Student's t-test, Mann Whitney $\mathrm{U}$ test and Wilcoxon rank sum test. Pearson correlation coefficient and logistic regressions were also used for correlations and to determine the risk factors. P-value $<0.05$ was considered significant.

A total of 105 children were included in the study. The patient demographics presented the mean age as $11.31 \pm 4.18$ years, female/male ratio $1 / 1.4$ and body mass index $18.48 \pm 4.48$. Children were classified as mild DKA (29.5\%), moderate DKA (35.2\%) and severe DKA (35.2\%) based on the acidosis severity. Weight loss occurred as the major complaint overall (68.2\%). $30.5 \%$ of the study population manifested altered consciousness only one had to intubated and received mechanical ventilation support. Timing of DKA resolution was $14.30 \pm 6.43$ hours. The demographics and the laboratory outcome are represented at Table 1 and 2. 
Table 1. The study demographics

\begin{tabular}{|c|c|c|c|}
\hline & $n=105(\%)$ & & $\begin{aligned} n & =105 \\
(\%) & \end{aligned}$ \\
\hline Gender, $(n)$ & & \multicolumn{2}{|l|}{ DKA severity } \\
\hline Female & $49(46.7 \%)$ & Mild & $31(29.5 \%)$ \\
\hline Male & $56(53.3 \%)$ & Moderate & $37(35.2 \%)$ \\
\hline Age (years),(meant $\pm S D)$ & $11.31 \pm 4.18$ & $\begin{array}{l}\text { Severe } \\
\text { Length of DKA resolution, } \\
\text { (saat), (ort } \pm S S)\end{array}$ & $\begin{array}{l}37(35.2 \%) \\
14.30 \pm 6.43\end{array}$ \\
\hline Height, $(\mathrm{cm}),($ mean $\pm S D)$ & $135.66 \pm 22.98$ & Altered consciousness, $(n)$ & $32(30.5 \%)$ \\
\hline Height SDS median(min-max) & $-0.84(-5.05-5.10)$ & Kusmaul respiration, $(n)$ & $51(48.6 \%)$ \\
\hline Weight, $(\mathrm{kg}),($ mean $\pm S D)$ & $35.97 \pm 16.31$ & Infection history, $(n)$ & $58(55.2 \%)$ \\
\hline Weight SDS, median(min-max) & $-0.62(-7.43-2.39)$ & Weight loss, $(n)$ & $72(68.6 \%)$ \\
\hline BMI, $(\%),($ mean $\pm S D) *$ & $18.48 \pm 4.48$ & Abdominal pain, $(n)$ & $36(34.3 \%)$ \\
\hline PRISM-3 score, $($ mean $\pm S D)$ & $11.87 \pm 5.47$ & Polydipsia., (n) & $48(45.7 \%)$ \\
\hline $\begin{array}{l}\text { Length of PICU stay, (days), } \\
(\text { mean } \pm S D)\end{array}$ & $2.06 \pm 1.01$ & Polyurea, $(n)$ & $47(45.7 \%)$ \\
\hline $\begin{array}{l}\text { Length of hospitalization, } \\
(\text { days }),(\text { mean } \pm S D)\end{array}$ & $7.31 \pm 2.11$ & Malaise, $(n)$ & $32(30.5 \%)$ \\
\hline \multirow{2}{*}{$\begin{array}{l}\text { New-onset of diabetes mellitus, } \\
(n)\end{array}$} & $54(51.4 \%)$ & Nausea, $(n)$ & $36(34.3 \%)$ \\
\hline & & Vomiting, $(n)$ & $26(24.8 \%)$ \\
\hline
\end{tabular}

*BMI: body mass index

Tablo 2. Laboratory outcome of the study population

\begin{tabular}{|c|c|}
\hline & $n(\%)$ \\
\hline \multicolumn{2}{|l|}{ Blood gas (venous), (mean $\pm S D)$} \\
\hline$p H$ & $7.13 \pm 0.12$ \\
\hline $\mathrm{PCO} 2(\mathrm{mmHg})$ & $23.87 \pm 7.18$ \\
\hline $\operatorname{HCO3}^{-}(m e q / L)$ & $8.05 \pm 4.11$ \\
\hline $\boldsymbol{B E},(\mathrm{mmol} / \mathrm{L})$ & $-18.38 \pm 6.38$ \\
\hline $\mathbf{B U N},(m g / d L),(m e a n \pm S D)$ & $15.32 \pm 6.16$ \\
\hline Serum creatinine, $(m g / d L),($ mean $\pm S D)$ & $0.76 \pm 0.31$ \\
\hline Serum glucose, $(m g / d L),($ mean $\pm S D)$ & $448.26 \pm 171.16$ \\
\hline Serum sodium, $(\mathrm{mmol} / \mathrm{L}),($ mean $\pm S D)$ & $134.50 \pm 3.91$ \\
\hline Correctred sodium, $(\mathrm{mmol} / \mathrm{L}),($ mean $\pm S D)$ & $140.07 \pm 4.13$ \\
\hline Serum chloride, $(\mathrm{mmol} / \mathrm{L}),($ mean $\pm S D)$ & $101.38 \pm 5.77$ \\
\hline Serum potassium $(\mathrm{mmol} / \mathrm{L}),($ mean $\pm S D)$ & $5.03 \pm 0.65$ \\
\hline Serum phosphate $(m g / d L),($ mean $\pm S D)$ & $3.94 \pm 1.22$ \\
\hline Anion gap, $(\mathrm{mmol} / \mathrm{L}),($ mean $\pm S D)$ & $24.67 \pm 5.41$ \\
\hline Calculated osmolality $(\mathrm{mOsm} / \mathrm{kg})$ & $293.91 \pm 10.58$ \\
\hline White blood cell count $\left(\mathrm{mm}^{3}\right)$ & $12860 \pm 7470$ \\
\hline HbA1c, $(\%),($ mean $\pm S D)$ & $12.16 \pm 2.66$ \\
\hline C-peptide, $(n g / m l),($ mean $\pm S D)$ & $0.81 \pm 0.60$ \\
\hline
\end{tabular}

Children with new onset of diabetes accounted for $51.4 \%$ of the study population. The mean age was $9.70 \pm 4.47$ years; this group constituted a younger population compared the established DM patients ( $\mathrm{p}<0.001$; Table 3). Altered mental state and kusmaull respiration also occurred at a higher rate and the major complaint seemed ae weight loss within two weeks ( $\mathrm{p}=0.006, \mathrm{p}=0.002, \mathrm{p}<0.001$ respectively). On the other hand, children with established diabetes mellitus presented significant biochemical abnormalities in terms of elevated BUN and serum potassium levels $(\mathrm{p}<0.001$, $\mathrm{p}<0.001$; Table 4); infections occurred as the major triggering factor for DKA at a rate of $80.4 \%$ at this group.

Table 3. The demograhics and the clinical outcome according to timing of DM diagnosis 


\begin{tabular}{|c|c|c|c|c|c|c|c|}
\hline \multirow{3}{*}{ Gender, $(n)$} & \multirow[t]{2}{*}{$\begin{array}{c}\text { New-onset DM } \\
(n=54)\end{array}$} & \multirow[t]{2}{*}{$\begin{array}{l}\text { Established DM } \\
\qquad(n=51)\end{array}$} & $p$ & New-onset DM & \multicolumn{2}{|c|}{$\begin{array}{c}\text { I Established DM } \\
(n=54)\end{array}$} & \multirow{2}{*}{$\frac{(n=51)}{<0.001}$} \\
\hline & & & & $\begin{array}{l}\text { Leng th of DKA resolution, } \\
\text { (hours), (mean } \pm S D)\end{array}$ & $\begin{array}{c}16,89 \pm 5,9 \\
1\end{array}$ & $11.50 \pm 5.81$ & \\
\hline & $26(48.1 \%)$ & $23(45.1 \%)$ & 0.754 & & & & \\
\hline Male & $28(51.9 \%)$ & $28(54.9 \%)$ & & & & & \\
\hline Age $($ years $)($ mean $\pm S D)$ & $9.70 \pm 4.47$ & $13.01 \pm 3.06$ & $<0001$ & Altered consciousness $(n)$ & $23(42.6 \%)$ & $9(17.6 \%)$ & 0.006 \\
\hline Height $(\mathrm{cm})($ mean $\pm S D)$ & $131.82 \pm 26.40$ & $139.72 \pm 18.22$ & 0.297 & Kusmaul respiration, $(n)$ & $34(63 \%)$ & $17(33.3 \%)$ & 0.002 \\
\hline Height SDS, median (min-max) & $-0.058(-2.91-5.10)$ & $-1.01(-5.05-0.671)$ & 0.002 & Infection history, $(n)$ & $17(31.5 \%)$ & $41(80.4 \%)$ & $<0.001$ \\
\hline Weight, $(k g),($ mean $\pm S D)$ & $34.37 \pm 18.03$ & $37.66 \pm 14.35$ & 0.341 & Weight loss, $(n)$ & $49(90.7 \%)$ & $23(45.1 \%)$ & $<0.001$ \\
\hline Weight SDS, median(min-max) & $-0.27(-7.03-2.39)$ & $-0.78(-7.43-1.97)$ & 0.024 & Abdominal pain, $(n)$ & $21(38.9 \%)$ & $15(29.4 \%)$ & 0.307 \\
\hline BMI $(\%),($ mean $\pm S D)$ & $18.19 \pm 4.31$ & $18.78 \pm 4.70$ & 0.611 & Polydipsia. $(n)$ & $42(77.8 \%)$ & $6(11.8 \%)$ & $<0.001$ \\
\hline $\begin{array}{l}\text { DKA severity } \\
\quad \text { Mild } \\
\text { Moderate } \\
\text { Severe }\end{array}$ & $\begin{array}{l}17(31.5 \%) \\
20(37.0 \%) \\
17(31.5 \%)\end{array}$ & $\begin{array}{l}14(27.5 \%) \\
17(33.3 \%) \\
20(39.2 \%)\end{array}$ & 0.708 & Polyurea, $(n)$ & $41(75.9 \%)$ & $6(11.8 \%)$ & $<0.001$ \\
\hline PRISM-3 score, $($ mean $\pm S D)$ & $12.71 \pm 6.45$ & $11.22 \pm 4.59$ & 0.431 & Malaise, $(n)$ & $22(40.7 \%)$ & $10(19.6 \%)$ & 0.019 \\
\hline $\begin{array}{l}\text { Length of PICU stay, } \\
(\text { days })(\text { mean } \pm S D)\end{array}$ & $2.44 \pm 0.86$ & $1.66 \pm 1.02$ & $<0.001$ & Nausea, $(n)$ & $19(35.2 \%)$ & $17(33.3 \%)$ & 0.842 \\
\hline $\begin{array}{l}\text { Length of hospitalization, } \\
(\text { days }),(\text { mean } \pm S D)\end{array}$ & $8.75 \pm 1.03$ & $5.78 \pm 1.89$ & $<0.001$ & Vomiting, $(n)$ & $19(35.2 \%)$ & $7(13.7 \%)$ & 0.011 \\
\hline
\end{tabular}

Table 4. Laboratory outcome of the study population

\begin{tabular}{|c|c|c|c|}
\hline & $\begin{array}{c}\text { New onset DM } \\
(n=54)\end{array}$ & $\begin{array}{c}\text { Established DM } \\
(n=51)\end{array}$ & $p$ \\
\hline \multicolumn{4}{|l|}{ Bllod gas (venous), (mean $\pm S D$ ) } \\
\hline pH & $7.13 \pm 0.14$ & $7.14 \pm 0.11$ & 0.730 \\
\hline PCO2 $(\mathrm{mmHg})$ & $23.15 \pm 6.24$ & $22.65 \pm 8.06$ & 0.286 \\
\hline HCO3 $(m e q / L)$ & $8.31 \pm 4.33$ & $7.76 \pm 3.88$ & 0.742 \\
\hline$B E,(\mathrm{mmol} / \mathrm{L})$ & $-18.04 \pm 6.76$ & $-18.75 \pm 5.99$ & 0.699 \\
\hline BUN, $(m g / d L),(m e a n \pm S D)$ & $12.59 \pm 3.70$ & $18.22 \pm 6.91$ & $<0.001$ \\
\hline Serum creatinine, $(m g / d L),(m e a n \pm S D)$ & $0.73 \pm 0.27$ & $0.80 \pm 0.35$ & 0.271 \\
\hline Serum glucose, $(\mathrm{mg} / \mathrm{dl}),($ mean $\pm S D)$ & $464.83 \pm 166.99$ & $430.72 \pm 175.40$ & 0.469 \\
\hline Serum sodium, $(\mathrm{mmol} / \mathrm{L}),($ mean $\pm S D)$ & $134.85 \pm 4.25$ & $134.13 \pm 3.52$ & 0.451 \\
\hline Corrected sodium, $($ mean $\pm S D)$ & $140.68 \pm 4.42$ & $139.42 \pm 3.74$ & 0.119 \\
\hline Serum chloride, $(\mathrm{mmol} / \mathrm{L}),($ mean $\pm S D)$ & $101.87 \pm 6.38$ & $100.86 \pm 5.06$ & 0.827 \\
\hline Serum potassium, $(\mathrm{mmol} / \mathrm{L}),($ mean $\pm S D)$ & $4.81 \pm 0.46$ & $5,27 \pm 0.73$ & $<0.001$ \\
\hline Serum phosphate $(m g / d l),($ mean $\pm S D)$ & $3.75 \pm 1.08$ & $4.13 \pm 1.33$ & 0.081 \\
\hline Anion gap, $(\mathrm{mmol} / \mathrm{L})$ & $24.20 \pm 5.45$ & $25.17 \pm 5.38$ & 0.356 \\
\hline Calculated osmolality, $(\mathrm{mOsm} / \mathrm{kg})$ & $295.52 \pm 10.91$ & $292.20 \pm 10.06$ & 0.157 \\
\hline $\mathbf{W B C}\left(\mathrm{mm}^{3}\right)^{*}$ & $11500 \pm 6185$ & $14270 \pm 8440$ & 0.143 \\
\hline HbA1c, $(\%),($ mean $\pm S D)$ & $11.95 \pm 2.68$ & $12.47 \pm 2.63$ & 0.251 \\
\hline C-peptide, $(n g / m l),($ mean $\pm S D)$ & $0.85 \pm 0.58$ & $0.84 \pm 0.96$ & 0.111 \\
\hline
\end{tabular}

*WBC: White blood cell count 
Table 5. Risk Factors Assciated with DKA resolution

\begin{tabular}{|c|c|c|c|c|c|}
\hline \multicolumn{4}{|c|}{ Time of DKA resolution } & \multicolumn{2}{|c|}{ Time of DKA resolution } \\
\hline \multirow[t]{2}{*}{ Age } & $p$ & 0.230 & Anion gap & $p$ & 0.001 \\
\hline & $r$ & -0.073 & & $r$ & 0.302 \\
\hline \multirow[t]{2}{*}{ Weight } & $p$ & 0.264 & Calculated osmolality & $p$ & 0.014 \\
\hline & $r$ & 0.078 & & $r$ & 0.215 \\
\hline \multirow[t]{2}{*}{ Weight SDS } & $p$ & 0.491 & BUN & $p$ & 0.103 \\
\hline & $r$ & 0.003 & & $r$ & -0.125 \\
\hline \multirow[t]{2}{*}{ BMI } & $p$ & 0.136 & Serum creatinine & $p$ & 0.007 \\
\hline & $r$ & 0.136 & & $r$ & 0.242 \\
\hline \multirow[t]{2}{*}{ PRISM-3 score } & $p$ & 0.222 & Serum sodium & $p$ & 0.413 \\
\hline & $r$ & 0.113 & & $r$ & 0.022 \\
\hline \multirow[t]{2}{*}{ Length of PICU stay } & $p$ & $<0.001$ & Corrected sodium & $p$ & 0.074 \\
\hline & $r$ & 0.842 & & $r$ & 0.143 \\
\hline \multirow[t]{2}{*}{ Length of hospitalization } & $p$ & $<0.001$ & Serum potassium & $p$ & 0.358 \\
\hline & $r$ & 0.429 & & $r$ & -0.036 \\
\hline \multirow[t]{2}{*}{ Blood gas pH } & $p$ & $<0.001$ & Serum chloride & $p$ & 0.065 \\
\hline & $r$ & -0.704 & & $r$ & 0.149 \\
\hline \multirow[t]{2}{*}{ PCO2 } & $p$ & $<0.001$ & Serum phosphate & $p$ & 0.464 \\
\hline & $r$ & 0.429 & & $r$ & 0.009 \\
\hline \multirow[t]{2}{*}{$\mathrm{HCO3}^{-}$} & $p$ & $<0.001$ & Serum glucose & $p$ & 0.011 \\
\hline & $r$ & -0.694 & & $r$ & 0.224 \\
\hline \multirow[t]{2}{*}{ BE } & $p$ & $<0.001$ & HbA1c & $p$ & 0.223 \\
\hline & $r$ & -0.689 & & $r$ & 0.68 \\
\hline
\end{tabular}

Table 5 represents the correlations between timing of DKA resolution and biochemical/blood gas parameters. We observed a positive correlation with DKA resolution with serum creatinine, calculated osmolality, anion gap $(\mathrm{r}=0.242$, $\mathrm{r}=0.215, \mathrm{r}=0.302$ ) and a negative correlation with blood gas $\mathrm{pH}$ and $\mathrm{HCO} 3(\mathrm{r}=-0.704, \mathrm{r}=-0.694)$. In the multivariable regression model including age, gender, body mass index, PRISM-3 score, BUN, serum potassium, phosphate and chloride, only blood gas $\mathrm{pH}$ and new onset of diabetes appeared to be the independent risk factors for DKA resolution. 0.1 unit decrement in blood gas $\mathrm{pH}$ elongated the resolution by 3.76 hours $(\mathrm{p}<0.001$, adjusted ratio: 0.743). New onset of diabetes mellitus also increased the length of resolution 5.30 hours $(\mathrm{p}<0.001)$.

In terms of complications, $30.5 \%$ of the study population manifested altered consciousness; only one had tomography-proven brain edema. The same patient had to intubated and received mechanical ventilation support for three days due to neurological incapability to sustain airway maneuvers. Another four patients (one from newonset of diabetes, three from established-DM groups) developed acute kidney injury (AKI); one patient required hemodialysis due to intractable acidosis. Following two sessions of dialysis, kidney functions were restored. There was not any recorded mortality due to DKA. We observed total length of PICU stay and hospitalization as $2.06 \pm 1.01$ days and $7.31 \pm 2.11$ days respectively.

\section{DISCUSSION}

The results of this study demonstrated, i) blood gas $\mathrm{pH}$ predicted the timing of DKA resolution ( 0.1 unit decrement in $\mathrm{pH}$ elongates the resolution by 3.76 hours; adjusted ratio: 0.743 ); ii) new onset of diabetes mellitus delayed the restoration of metabolic balance by 5.3 hours; iii) baseline creatinine level, anion gap and calculated serum osmolality significantly correlated with resolution time.

The influence of blood gas $\mathrm{pH}$ and $\mathrm{HCO} 3$ on DKA severity have been well established ${ }^{10}$. The goal of therapy is the initiation of appropriate fluid and insulin medication to correct dehydration. ISPAD guideline refers to restoraiton of metabolic balance as blood gas (venous) $\mathrm{pH}>$ $7.3, \mathrm{HCO} 3>15 \mathrm{mmol} / \mathrm{L}^{5}$; however it does not establish the precise timing of DKS resolution. As far as we know, this was the first report to demonstrate the duration of DKA resolution in children. We found, 0.1 unit decrement in venous blood gas $\mathrm{pH}$ elongated the resolution by 3.76 hours ( $p>0.001$, adjusted ratio: 0.743 ).

The new onset of diabetes had also distinct characteristics in this study. They encountered altered mental state and kusmaull respiration more 
frequently; possible explanation for the latter was the lack of timely diagnosis. Delayed admission to a health care facility have exposed the child to longer periods of dehydration, causing severe clinical signs and symptoms. Thus restoration of metabolic balance was delayed by 5.3 hours compared to established DM children.

Several life threatining complications are demonstrated in literature with mortality rates ranging between $0.15 \%$ and $30 \%{ }^{5,11}$. The most feared consequence is the cerebral edema. Although the underlying mechanism of brain edema is contraversial, several mechanisms might play a role such as rapid deterioration of cerebral osmolarity due to inappropriate fluid treatment and cerebral hypoperfusion-related cerebral injury ${ }^{11-14}$. The incidence of tomography-proven brain edema is reported $0.5 \%-0.9 \%$, but the actual rates are believed to be higher. The subclinical edema occurs frequently, but often unrecognized $^{14}$. If left untreated, the mortality due to edema might reach up to $21 \%-24 \%$. Brain edema has a long term sequelae on congnitive functions, fall intellectual coefficients, short term memory loss at a rate of $15 \%-35 \%{ }^{15}$. In the present study, only one patient was complicated with cerebral edema $(0.9 \%)$, in which the rates were concardant with literature reports ${ }^{16,17}$.

Another serious consequence of DKA is the development of AKI. Despite the fact that, AKI occurs at a higher rate in hyperglycemic hypoerosmolar state, it's incidence on children with DKA is scarce ${ }^{18,19}$. The recent report from Weissbach et al, demonstrated the AKI incidence at DKA presence as $30 \%$ possibly due to prerenal mechanisms ${ }^{20}$. No doubt in the management of DKA, AKI poses a greater risk for the patient, because children exhibit serious challenge than adults for several reasons. First of all, the younger the age, more difficult to obtain a brief symptom history which leads to increased length of periods left undiagnosed. The longer the patient is undiagnosed, the higher risk of patient exposing to hypovolemia and dehydration. Secondly, the management of fluid therapy is harder in children due to higher metabolic rate and relatively large surface are to body mass ${ }^{20}$. Besides, several investigators report severe metabolic acidosis on the onset of DKA which do not improve despite adequate therapy ${ }^{21-23}$. Our results indicated four children had AKI (one in new onset of DM, three in established DM diagnosis groups). Only one with established DM diagnosis required hemodialysis due to intractable acidosis. AKI progression in this study supported AKI incidence reporting higher incidence in established DM diagnosis in other studies ${ }^{24}$. Possible explanation for higher incidence is the chronic exposure to elevated blood sugar and microvascular renal damage.

In the present study, the rate of new onset of diabetes was $51.4 \%$. Other studies report the incidence as $8.6 \%-67 \%{ }^{25,26}$. The significantly wide ranges in the reported incidence might be due to several reasons such as: DKA criteria designed for the study, the prevalence of DM in the index population, the socioeconomic income of the country and racial differences ${ }^{26,27}$. Children less than 2 years of age and adolescents between 10 and 14 years have higher DKA prevalence than other age groups ${ }^{28}$. The dominance of new onset of diabetes of this study might be explained by relatively older age of children who were enrolled in the study. Our results were consistent with the reports from Polish, Pakistanian and Iranian children demostrating the average age groups at the new onset of diabetes ${ }^{26,29,30}$.

There were some limitations of the study. The retrospective nature of this study brought along the risk of potantial conflict of bias. Secondly for the new onset of diabetes group, we did not had any chance to form a control diabetic group without ketoacidosis; thus other associated risk factors related with new onset of diabetes could not be examined. Finally, the number of children enrolled in the study were quite small to generalize the outcomes to the whole population. On the other hand, the strength of this study was to predict the timing at DKA resolution and restoration of metabolic balance. Plus the significant infection rates and DKA relationship in children with established diabetes mellitus compel the attraction on parental education of having a diabetic youngster. Health care professionals should address the increased insulin demand in presence of infections on family meetings. In addition, all health care practitioners should be encouraged to identify early symptoms of diabetes mellitus.

\section{REFERENCES}

1. Del Pozo P, Aránguiz D, Córdova G Scheu C, Valle P, Cerda J, García H, Hodgson MI, Castillo A. Clinical profile of children with diabetic ketoacidosis in fifteen years of management in a Critical Care Unit. Rev Chil Pediatr. 2018 Aug;89(4):491-498. doi: 10.4067/S0370-41062018005000703.

2. Wolfsdorf JI. The International Society of Pediatric and Adolescent Diabetes guidelines 
for management of diabetic ketoacidosis: Do the guidelines need to be modified? Pediatr Diabetes. 2014;15(4):277-86.

3. Olivieri L, Chasm R. Diabetic Ketoacidosis in the Pediatric Emergency Department. Emerg Med Clin N Am 2013;755-73.

4. Wolfsdorf J, Craig ME, Daneman D, et al. Diabetic ketoacidosis in children and adolescents with diabetes. Pediatr Diabetes. 2009; 10 Suppl 12: 118-33

5. Wolfsdorf JI, Glaser N, Agus M, Fritsch M, Hanas R, Rewers A, Sperling MA, Codner E. ISPAD Clinical Practice Consensus Guidelines 2018: Diabetic ketoacidosis and the hyperglycemic hyperosmolar state. Pediatr Diabetes. 2018 Oct;19 Suppl 27:155177. doi: 10.1111/pedi.12701.

6. Usher-Smith JA, Thompson MJ, Walter FM. Variation between countries in the frequency of diabetic ketoacidosis at first presentation of type 1 diabetes in children: a systematic review. Diabetologia. 2012; 55(11):2878- 94.

7. Long B, Koyfman A. Emergency Medicine Myths: Cerebral Edema in Pediatric Diabetic Ketoacidosis and Intravenous Fluids. J Emerg Med. 2017 Aug;53(2):212-221. doi: 10.1016/j.jemermed. 2017.03.014. Epub 2017 Apr 12.

8. Sherry N, Levitsky L. Managment of Diabetic Ketoacidosis in Children and Adolescents. Pediatr Drugs. 2008; 10(4):20915.

9. Gülser Esen Besli Başak Nur Akyıldız Hasan Ağın. Çocuk acil tıp ve yoğun bakım derneği. Diabetik ketoasidoz tedavi protokolü 2017. Available at: http://www.cayd.org.tr/gorseller /files/protokoller/CAYDDKA(07012018).pdf

10. Wolfsdorf JI, Allgrove J, Craig ME, Edge J, Glaser N, Jain V, Lee WW, Mungai LN, Rosenbloom AL, Sperling MA, Hanas R: ISPAD Clinical Practice Consensus Guidelines 2014. Diabetic ketoacidosis and hyperglycemic hyperosmolar state. Pediatr Diabetes 2014;15 Suppl 20:154-179.

11. Duck SC, Wyatt DT: Factors associated with brain herniation in the treatment of diabetic ketoacidosis. J Pediatr 1988;113:10-14.

12. Glaser N, Barnett P, McCaslin I, Nelson D, Trainor J, Louie J, Kaufman F, Quayle K, Roback M, Malley R, Kuppermann N: Risk factors for cerebral edema in children with diabetic ketoacidosis. The Pediatric Emergency Medicine Collaborative Research Committee of the American Academy of Pediatrics. N Engl J Med 2001;344:264-269.

13. Yuen N, Anderson SE, Glaser N, Tancredi DJ, O'Donnell ME: Cerebral blood flow and cerebral edema in rats with diabetic ketoacidosis. Diabetes 2008;57:2588-2594.

14. Glaser NS, Wootton-Gorges SL, Buonocore MH, Marcin JP, Rewers A, Strain J, DiCarlo J, Neely EK, Barnes P, Kuppermann N: Frequency of sub-clinical cerebral edema in children with diabetic ketoacidosis. Pediatr Diabetes 2006;7:75-80.

15. Jefferies CA, Nakhla M, Derraik JG, Gunn AJ, Daneman D, Cutfield WS. Preventing Diabetic Ketoacidosis. Pediatr Clin North Am. 2015; 62(4): 857-71.

16. Edge JA, Hawkins MM, Winter DL, Dunger DB: The risk and outcome of cerebral oedema developing during diabetic ketoacidosis. Arch Dis Child 2001;85:16-22.

17. Lawrence SE, Cummings EA, Gaboury I, Daneman D: Population-based study of incidence and risk factors for cerebral edema in pediatric diabetic ketoacidosis. J Pediatr 2005;146:688-692

18. Baalaaji M, Jayashree M, Nallasamy K, Singhi S, Bansal A. Predictors and Outcome of Acute Kidney Injury in Children with Diabetic Ketoacidosis. Indian Pediatr. 2018 Apr 15;55(4):311-314. Epub 2018 Feb 9.

19. Zeitler P, Haqq A, Rosenbloom A, Glaser N; Drugs and Therapeutics Committee of the Lawson Wilkins Pediatric Endocrine Society. Hyperglycemic hyperosmolar syndrome in children: pathophysiological considerations and suggested guidelines for treatment. J Pediatr. 2011;158:9-14,14.e1-2.

20. Weissbach A, Zur N, Kaplan E, Kadmon G, Gendler Y, Nahum E. Acute Kidney Injury in Critically Ill Children Admitted to the PICU for Diabetic Ketoacidosis. A Retrospective Study. Pediatr Crit Care Med. 2019 Jan;20(1):e10-e14.doi: 10.1097/PCC.0000000000001758.

21. Yesilbas O, Cem E, Cimbek EA. Successful treatment of life-threatening severe metabolic acidosis by continuous veno-venous hemodialysis in a child with diabetic ketoacidosis. J Pediatr Endocrinol Metab. 2018 Sep 25;31(9):1043-1045. doi: 10.1515/jpem-2018-0232.

22. Lee SH, Kim BG, Cho AY, Kim SS, Shin HS, et al. A case of diabetic ketoacidosis with refractory metabolic acidosis successfully treated with continuous hemodiafiltration. J Korean Soc Emerg Med 2015;26:480-482.

23. Kawata H, Inui D, Ohto J, Miki T, Suzue A, et al. The use of continuous hemodiafiltration in a patient with diabetic ketoacidosis. J Anesth 2006;20:129-31 
24. Jefferies C, Cutfield S, Derraik JG, Bhagvandas J, Albert BB, Hofman PL, et al. 15-year incidence of diabetic ketoacidosis at onset of type 1 diabetes in children from a regional setting (Auckland, New Zealand). Sci Rep. 2015;5:10358.

25. Sola E, Garzon S, Garcia-Torres S, Cubells $\mathrm{P}$, Morillas C, Hernandez-Mijares A: Management of diabetic ketoacidosis in a teaching hospital. Acta Diabetol 2006;43:127-130.

26. Jawaid A, Sohaila A, Mohammad N, Rabbani U: Frequency, clinical characteristics, biochemical findings and outcomes of DKA at the onset of type-1 DM in young children and adolescents living in a developing country - an experience from a pediatric emergency department. J Pediatr Endocrinol Metab 2019;32:115-119.

27. Onyiriuka AN, Ifebi E: Ketoacidosis at diagnosis of type 1 diabetes in children and adolescents: frequency and clinical characteristics. J Diabetes Metab Disord 2013;12:47.

28. Hekkala A, Reunanen A, Koski M, Knip M, Veijola R: Age-related differences in the frequency of ketoacidosis at diagnosis of type 1 diabetes in children and adolescents. Diabetes Care 2010;33:1500-1502.

29. Chumiecki M, Prokopowicz Z, Deja R, Jarosz-Chobot P: [Frequency and clinical manifestation of diabetic ketoacidosis in children with newly diagnosed type 1 diabetes]. Pediatr Endocrinol Diabetes Metab 2013;19:143-147.

30. Razavi Z: Frequency of ketoacidosis in newly diagnosed type 1 diabetic children. Oman Med J 2010;25:114-117. 